\title{
How Land Use Law Impedes Transportation Innovation
}

\author{
David Schleicher
}

Necessity, it is said, is the mother of invention. ${ }^{1}$ This wonderful volume studies innovation in housing policy. This chapter asks why we need innovation in our housing policy, or rather what is changing to make our current housing policy inappropriate, to the extent that it made sense in the first place. I argue that changing transportation technologies have created opportunities for economic growth, but that land use regulations and other housing policies reduce the gains from these technological improvements. In order to capture the gains from new transportation technologies, and to help reverse the slow economic growth we have seen in the United States in most of the period since 1970, we need a housing policy that matches our current (and future) transportation system.

\section{$* * *$}

In discussions of the American economy, the transportation industry and transportation innovation plays a central role. Politicians regularly point to the health of the transportation industry as an indicator of the economy's broader well-being. Think of Charles Wilson's famous (mis)quote that "what's good for General Motors is good for the United States.” Or of President Obama's argument that, as a result of a federal bailout, the auto industry is now "leading the way" toward a type of economic growth that benefits middle-class Americans (Miller 2015; Patterson 2013).

Similarly, scholars attempting to project economic growth often focus on transportation innovation. Techno-optimists like Erik Brynjolfsson and Andrew McAfee point to innovations like self-driving cars and drones and predict rates of growth on par with the Industrial Revolution (Brynjolfsson and McAfee 2014, 1-12). Skeptics like Robert Gordon argue that growth has been slow since 1970 and will continue to be so based on their assessment of the likely effects of the same technologies (Gordon 2014).

But transportation innovation does not create economic growth in the same way as innovation in other sectors. ${ }^{2}$ For the most part, people do not directly consume the benefits of innovative transportation technology, nor is its direct use a major factor in determining whether businesses can produce goods more cheaply or more 
efficiently. Most of the benefits of transportation innovation do not come from faster and easier travel to existing homes, offices, and businesses.

Instead, transportation innovations allow us to move our homes, offices, factories, and stores into more pleasing and efficient patterns. Early automobiles, for example, were not much more effective than streetcars or even horses at navigating the crowded and pockmarked streets of dense, urban cores (Foster 1981, 9-24; Norton 2011). But cars allowed people and firms to spread outward across a region, creating new opportunities for suburban life, particularly following substantial public investment in roads designed for automobiles (Mohl and Biles 2012, 204-06). Likewise, the elevator, on its own, would not have provided many benefits to residents of cities; elevators are not that much better than stairs in existing low-rise buildings. ${ }^{3}$ But elevators make the use of taller buildings possible, increasing a city's capacity for density. While transportation innovations provide some benefits to people making their existing commutes, the bulk of the economic gains from transportation innovations comes from changes in patterns of land use.

Transportation scholars have long known that infrastructure investments both depend on current land use patterns and spur changes in those patterns. There is a massive literature built around what are known as Land Use Transport Interaction (LUTI) models, which analyze the complex interrelationship between infrastructure investments, land use, and transportation developments (Van Wee 2015; Wegener 2014).

But the scholars and practitioners in the field (and their increasingly complex software) almost entirely ignore the ubiquity of legal limitations on land use. In comprehensively planned cities, market forces do not, on their own, determine the flow of benefits to the broader economy from transportation innovations or investments. If one wants to know how a road or light rail line will affect land uses in a comprehensively regulated city or region, one must understand both the content of zoning and other regulations - rules governing what can be built, where, and how it can be used - and the politics of changing these regulations. New housing, for instance, will not simply emerge around new highways or rail lines. Governments must allow the market to work by revising zoning and subdivision ordinances that accommodate construction.

The same logic applies to new transportation technologies. The kinds and amounts of gains from advances in transportation technology depend heavily on how land use law reacts (or, sometimes, overreacts) to their presence.

This chapter will assess how well modern land use law has or might accommodate three major recent or soon-to-arrive transportation innovations: (1) global positioning systems (GPS), mobile mapping, and real-time traffic information services (like Google Maps, Apple Maps, TomTom, Garmin, and Waze); (2) e-hailing apps for taxis, shared rides, and shuttles (like Uber, Lyft, and their competitors); ${ }^{4}$ and (3) stilldeveloping self-driving autonomous cars. 
These technological innovations should allow two separate types of changes to land use patterns.

First, they will allow what I will call "distributed density" within urban areas. Each technology should allow for more overall density in cities. To varying degrees, they make travel through dense areas easier, allow for more efficient use of existing infrastructure, and reduce the costs of congestion (and need for parking spaces) for a given density of people and businesses. Further, the advantages of these developments do not depend on extreme density. Nodes of heavy density (e.g., stores along a high street, or apartments within a quarter of a mile of a train station) may spread a bit further outward without losing the gains of agglomeration. Regions will maximize the economic gains from these technologies if they allow dense and diverse development - if buyers can choose townhouses or apartments in towers.

Second, the innovations will allow development to spread around cities, as they particularly GPS and potentially autonomous cars - reduce the costs of traveling substantial distances, both in time and in effort (Anderson et al. 2014).

But modern land use law does not equally allow both of these types of development. Land use law and politics are particularly ill-equipped to produce distributed density. Its deep procedural rules and the multiple ways current residents can block new construction make incremental housing growth particularly difficult (Hills and Schleicher 2011, 81-89). While massive new projects sometimes can run the gauntlet of the zoning amendment process, environmental review and Not In My Backyard (NIMBY) political opposition, developers and homeowners proposing incremental changes in existing neighborhoods often cannot afford the lawyers and lobbyists necessary to do so (Platt 2004, 317-20).

These limitations on "distributed density" precede transportation innovations like Uber and GPS. Housing advocates have started discussing the "missing middle" of the housing market - townhouses, two-tops, triple deckers, etc. - that flourished before modern zoning rules, but that are now almost impossible to construct (Hurley 2016; Schleicher 2013). Similarly, U.S. land use regulations excessively keep retail out of residential zones, separating land uses more than any other advanced economy (Hirt 2013). Finally, and most pressingly, land use regulations substantially harm the regional and national economies by limiting overall density in many rich regions and cities, a trend that really took off in the 1970s and 1980s, as Bill Fischel details in Chapter 1 of this volume (Hsieh and Moretti 2015; Schleicher 2013). In contrast, the fringes of metropolitan areas are less regulated, so these transportation innovations should allow our metropolitan areas to spread further.

This leads to two basic predictions. In downtowns and heavily zoned metropolitan areas, the land usages that zoning regulations allow will fall even shorter of what is economically ideal. Today's urban and inner-ring suburban zoning politics will undercut future opportunities to restructure housing and retail. Innovations in transportation will increase the cost of our dysfunctional land use law regime. Further, land use law will hinder further transportation innovation. The incentive 
to develop, say, autonomous taxis will be lower in less dense cities. If we hope to maximize the gains from transportation innovation and avoid biasing future technology innovations, ${ }^{5}$ we must reform land use regimes, particularly in the richest metropolitan areas.

\subsection{AN INTRODUCTION TO TRANSPORTATION AND AGGLOMERATION ECONOMIES}

To discuss new transportation technologies, I lay out a simple model of how transportation technologies interact with land usage generally. This section will discuss (a) the interaction between transportation technology and urban economic activity, and (b) how the study of the economic effect of zoning on regional economies can tell us how to study the economic impact of transportation technologies.

\subsection{A Transportation Technologies and Agglomeration Economies}

All analyses of urban economies start with the same basic question: why do people and firms move to cities? (Glaeser 2008a). Economists usually describe three basic types of "agglomeration economies," or gains from density (Marshall 1890; Schleicher 2010, 1517-28).

The first kind of agglomeration economies deal with shipping costs for goods. Intermediate goods manufacturers can save on shipping costs by moving closer to one another. Much of the history of American urban development turns on decisions by firms to reduce shipping costs by moving to cities (Glaeser and Kohlhase 2004, 198-99; Glaeser and Ponzetto 2007). Almost every major urban center in the United States developed around a major port or rail transport hub. As innovative transportation technologies (like the combustion engine or the shipping container) have driven transportation costs downward, though, manufacturing firms have less and less reason to move to urban areas (Schleicher 2013, 1551-52). Other factors better explain modern urbanization.

The second major category of agglomeration economies includes the benefits of deep markets. Workers in a particular metropolitan region can often participate in a deeper labor market (Rodriguez and Schleicher 2012, 640-47). Think of actors moving to Los Angeles. They can specialize (perhaps becoming an expert in one type of role), match more easily (find a studio that needs their specialty), invest in human capital development (acting school or private lessons), and insure themselves against firm-specific risk. These benefits do not accrue to similarly talented workers in rural areas or regions with less labor market depth.

Further, transportation technologies and infrastructure define the depth of a given labor market. Workers must be able to reach employers in order to work for them, a 
point clear to those who advocate that we give cars to the poor to increase their labor market opportunities (Logan and Molotch 1987, 262).

Depth matters in markets besides labor and in areas smaller than metropolitan ones, too. Retail markets benefit from market depth. Perhaps the most traditional form of retail development is the "high street," where various stores cluster along a single strip. By locating along one strip instead of spreading out through a neighborhood, stores can specialize (Schleicher 2010, 1522). Consider, for example, a stretch of restaurants and bars. They form "restaurant rows" because consumers can go to the street knowing that there will be lots of different options and that, if one place is too crowded, another place will have seats (Rodriguez and Schleicher 2012).

The third big category of agglomeration benefits is information spillovers. People learn from others, and so population density leads to more productive workers. As Alfred Marshall famously noted, in cities, "the mysteries of the trade become no mystery but are, as it were, in the air" (1890). Software developers and entrepreneurs move to Silicon Valley for more than just the deep labor markets and the California sun; they move to learn from other tech people over coffee or drinks (Rodriguez and Schleicher 2012, 651). Indeed, those who move to urban areas see faster wage growth as a result of learning (Glaeser and Mare 2001; Rodriguez and Schleicher 2012). Patent applications are much more likely to cite other research done in the same place (Jaffee 1993). Chance interactions between residents provide such substantial benefits that firms sometimes design their office space to generate "random" encounters. When Steve Jobs was at Pixar, he placed bathrooms in a central location in order to get different kinds of people to run into one another (Silverman 2013).

The key insight for this chapter is that people move to cities because being close to other people provides economic and social benefits that offset the higher costs for property (and congestion) in cities. ${ }^{6}$ As Edward Glaeser notes, "conceptually, a city is just the absence of space between people and firms" (2008b, 4). This "absence of space between people" is not mere physical space, but rather the ease of communal interaction, either intentionally or by chance. Two people on different sides of a wall are physically proximate, but will find it difficult to interact. ${ }^{7}$ Similarly, cultural differences can make even physically proximate people quite distant.

The central factors that translate proximity into interactions are the ease of travel and information. Before the invention of the automobile, people living in what are now suburbs of major cities could not participate in regional labor markets. Land that was quite physically proximate to downtown was used for low-intensity purposes like farming because there was no easy way to commute (Mohl and Biles 2012, 20405). Only those places attached to downtown by omnibuses and streetcars developed into suburbs, because they made commuting and thus participation in urban labor markets possible (Mohl and Biles 2012, 87-88). Information plays a similar role. On high streets, for example, stores benefit from colocation because shoppers can easily see nearby retailers. A physically close shop on a side street would not capture 
agglomeration benefits from being part of a deep market, since shoppers would never see it or know about it.

Urban economic models have always relied heavily on transportation costs to explain land use patterns. Starting with Von Thunen and going through Alonso and Mills in the 1970s, economists developed "mono-centric models" assuming that business would be done in the city center (Glaeser 2008a, 15-17; Schleicher 2010, 1516-17). Distance from the city center predicted the kind of economic activity of the land, be it farmland or housing; the longer it took to travel downtown, the less intense the land usage. Trade theorists like Masahira Fujita, Paul Krugman, and Tony Venables use shipping costs to predict where firms will locate (Fujita, Krugman, and Venables 1999; Krugman 1995). Transportation technologies determine urban fates.

This is true across types of agglomeration economies. The depth and quality of urban labor markets turn on the quality of urban transportation networks. Alain Bertaud writes: "The potential economic advantages of large cities are reaped only if workers, consumers, and suppliers are able to exchange labor, goods, and ideas with minimum friction and to multiply face-to-face contacts with minimum time commitments and cost. The productivity of a city with a growing population can increase only if travel between residential areas and firms and among firms' locations remains fast and cheap" (Bertaud 2014, 7; 2004). Studies across countries show that worker productivity correlates with the number of jobs reachable within 20 minutes and 60 minutes (Bertaud 2014, 10). Labor market depth depends on both housing density and ease of transportation.

Further, patterns of development are highly dependent on transportation technologies. As mentioned previously, suburbs developed first around horse-drawn omnibus stops, then near electric streetcar stops; most of these developments were within walking distance from the commuter stops (Foster 1981, 18-20; McShane and Tarr 2007). Cities, for good and ill, invested heavily in remaking streets for automobile traffic. These investments created much more distributed development across metropolitan regions (Foster 1981, 10). The automobile now allows suburban residents to participate in regional labor markets without paying for expensive urban real estate.

Of course, many people want to live in urban areas and are willing to make tradeoffs against housing prices (per square foot) to do so. And labor markets are not purely regional. People who work heavy-hour, high-pay jobs in finance, law, and technology frequently want to live in cities and do not want to commute, meaning firms have incentives to do so (Edlund, Machado, and Syiatschi 2015). And cities retain many agglomerative advantages due to information spillovers and market depth in other areas, from retail to dating markets. But the rise of the car is associated with spreading out in all directions around urban areas.

Implicit in this well-known insight that the car enabled "sprawl" lies an important concept. Descriptive accounts of transportation innovation must integrate land use. 
The importance of a new road or rail line depends on how this new infrastructure will change demand for homes and offices, and how, in turn, those changes will affect the use of the infrastructure.

All (good) modern transportation planning focuses on the endogeneity of land uses and transportation. Land Use Transport Interaction (LUTI) models study the effect of new transportation infrastructure on traffic and land usage (Aditjandra 2013; Wegener 2013). These studies recognize that causality points in all directions. To address these difficulties, these models have become unbelievably sophisticated, built around "activity-based and agent-based or microsimulation models working with high-resolution parcel or grid-cell data" and individualized to particular urban areas, making them costly and requiring lots of data and computing power (Wegener 2013).

Their basic idea, however, applies to transportation innovation. All transportation technologies decrease the transaction costs of travel and therefore interaction, allowing firms and people to better capture agglomeration economies. Elevators make possible taller buildings, allowing more firms to be closer together, and commuter rails allow more people to access the regional labor market.

But people cannot just relocate wherever new transportation makes it possible. First, transportation decisions themselves largely depend on state investment in roads, railroads, traffic controls, etc. Second, and more importantly for our purposes here, land use law constrains relocation choice.

Modern LUTI models do little to acknowledge that law and politics - not just market forces - determine land uses. In contemporary American cities, local governments restrict the height, place, and uses of buildings through zoning, subdivision laws, parking requirements, building codes, historic preservation laws, and more. U.S. urban development has been caused not only by the car, but also by regulations that limited denser development and therefore made sprawl necessary (Barron 2003). Compared to Europe, U.S. policies encourage (and even require) more sprawl, and both Europe and the United States encourage more sprawl than technological change alone would (Lewyn 2008). It is law and not just the market that determines how transportation technologies affect land usage.

While LUTI models and software have grown ever more sophisticated, they fail to take into consideration the content (and the pathologies) of land use law. As Michael Wegener has found, the most popular LUTI models are "are not prepared to model policies" (2013).

This failure bakes in a particular (and wrongheaded) assumption about politics. Burt van Wee reports that there is a saying among LUTI scholars that "in the long term, every light rail line is located correctly. That is, the new light rail line, and in particular its stations, will fuel land-use changes in the vicinity of stations" (2015). This assumes that land use planners will permit denser land use near train stations. There is no reason to believe that this will always be the case, at least in the United States. Just look at the lack of density around stations on one of the oldest (and the 
second busiest) commuter rail lines in the United States, the Metro-North that runs through Westchester and Connecticut. Even in the long run, density does not necessarily follow train construction. By ignoring politics, LUTI models effectively assume that land use regulation will not bias development. This is deeply wrong.

\subsection{B How Should We Think about Land Use Law and New Transportation Technologies?}

Over the past 30 or so years, there has been a rise of restrictive zoning in the richest metropolitan regions in the United States, as Bill Fischel shows forcefully in Chapter 1. Starting in the 1970s and 1980s, zoning restrictions (along with other land use regulations, like the historic preservation zones Lior Strahelivitz discusses in Chapter 5) began substantially limiting the construction of housing at the regional level (Fischel 2015; Ganong and Shoag 2014; Schleicher 2013). These land use restrictions have become increasingly strict and inefficient. Edward Glaeser, Joseph Gyourko, and Raven Saks have shown that land use regimes in major American urban areas have caused housing costs to rise far higher than the cost of constructing housing (2005).

These local inefficiencies harm the national economy. Enrico Moretti and Chang-Tai Hsieh, for example, analyze how local land use inefficiencies affect the national labor market. They use regional demand for labor, as expressed by the price of labor, to determine how many people would move to rich regions if they were not barred by restrictive land use regimes. They find that lifting land use restrictions and thus allowing labor to move to its optimal location would increase GDP by 13.5 percent (Hsieh and Moretti 2015, 3)!

Peter Ganong and Daniel Shoag have shown that a long-term trend of convergence in average wages and per-capita GDP between states slowed in the 1980s and then stopped entirely. The reason is that a number of rich states and regions made it harder for people to move there (Ganong and Shoag 2014). People want to move to San Francisco or southern Connecticut, but can't; land use regimes make housing construction difficult and thus drive up costs. When people move to less-rich places with cheaper housing, they indirectly harm the economy. As Glaeser notes: "[I]t's a bad thing for the country that so much growth is heading to Houston and Sunbelt sister cities Dallas and Atlanta. These places aren't as economically vibrant or as nourishing of human capital as New York or Silicon Valley. When Americans move from New York to Houston, the national economy simply becomes less productive" $(2008 \mathrm{c}) .^{8}$

The same idea applies within regions. People badly want to live in Silicon Valley towns like Cupertino or Mountain View, since they house the richest companies in the country. But limits on housing construction in these towns mean that people move to less desirable but cheaper locales. ${ }^{9}$ This displacement creates losses. As Daniel Rodriguez and I have argued, the micro-displacements created by excessive 
or inapt zoning generate deadweight losses as people are forced to move from the locations where their labor or leisure would be most valuable (Rodriguez and Schleicher 2012, 638). This is true even if there is, in aggregate, enough housing in a region. A lobbyist forced to move from Capitol Hill to Shirlington, VA, will learn less through information spillovers during chance dinners where legislative procedure is discussed. She will network and learn less, even if she keeps the same job. ${ }^{10}$

We can use a similar concept to understand the degree to which economies take advantage of transportation technologies. New transportation innovations will affect optimal land use patterns. But laws might not allow the changes that would maximize these gains. The difference between what is allowed and what should follow from the technology should be understood as lost potential output.

This is the basic strategy this chapter will employ. It will first ask what types of land use changes new technologies will encourage. It will then ask whether our land use law system is likely to allow such changes.

One caveat is worth mentioning: while land use regimes can undermine the potential of transportation technologies, the opposite is true as well. If our goal is to have certain types of land uses, we need to engineer (or limit) transportation systems to support them. Governments can use zoning to permit substantial density, but if there is no mass transit, it can be hard to support. Or governments can legislate for spread-out country living through regulations requiring large minimum-lot sizes and other zoning tools, but if locations are attractive enough because of access to transportation, people will cheat, moving more people into a house than are legally allowed, or secretly subdividing lots. For the purposes of this chapter, I will analyze land use policies for their effect on potential economic output created by transportation technologies. But to the extent that the goal of policy is not output or economic growth, but rather something else - the maintenance of traditional modes of living or some such - the question would be whether we should ban transportation technologies that undermine the land use regime, rather than the reverse.

\subsection{TODAY'S TRANSPORTATION INNOVATION AND DISTRIBUTED DENSITY}

This section will look at three major advances in transportation technology and ask what effects they should have on land use and why we might imagine that they have not.

\subsection{A Mapping and Location Technologies and Land Use: Where Should} Retail Locate in a World with GPS, Mobile Maps, Mobile Phones, and Waze?

While satellite-based vehicle tracking dates back to the late 1950s, the military developed the Global Positioning System (GPS) in the 1970s and 1980s (Brownell 2014; Pace 1995). In the mid-1980s, the federal government made GPS technology 
available for civilian use. In 1989, the Magellan Company developed a handheld navigation device, and in 1995, General Motors began including GPS devices in new cars. But these early devices were expensive and not particularly accurate. When President Clinton signed an order making "precision GPS" data available, the modern GPS was born. Standalone GPS devices from companies like Garmin, Mio, Navigon, Magellan, and TomTom flooded the market. Today, cell phones combine GPS technology with advanced mapping software, making it unbelievably easy to navigate a city or search for local shops.

There are three central interactions between these technologies and land uses. First, they alter traffic patterns. Services like Google Maps make finding shortcuts that circumvent traditional highways or through-roads much easier. Traffic on nontraditional roads therefore increases. Technologies like Waze (now owned by Google) enhance this effect. Waze incorporates traffic reports from drivers on the road into its mapping software, redirecting drivers away from delayed highways and onto side streets. Both ordinary mapping and social directions have disrupted the quiet lives of homeowners on residential streets (Vanderbilt n.d.). For instance, in fancy neighborhoods off the 405 in LA (like Brentwood), residents have falsely reported accidents on Waze to prevent the program from directing drivers to their streets (Wallace-Wells 2015).

From a broader perspective, the problem with mapping technologies sending people down residential streets is not that this disrupts existing patterns of land use. The problem is that zoning regulations distort the way the property market should respond to new technologies. For example, right now, retail locates along highways and major thoroughfares (think strip malls) because of the high amount of traffic. If new technologies spread traffic out, ${ }^{11}$ then the demand for retail should increase along the now-residential streets that serve as the alternative routes Google Maps or Waze prescribe. The highest value use of property along these streets would change from low-intensity uses like single-family homes into higher-intensity uses like retail and multifamily developments.

Thus, mapping and location technologies open more locations to more intense land uses. This constitutes a real economic gain. More properties can provide retail and hence lower costs for consumers. Mapping and location technologies ought to increase the density of retail in a given shopping area, but also distribute that density along more roads. But it can only produce these gains if land use law allows retail to emerge on these once-residential streets.

The second way mapping technologies can change retail locations is by reducing search costs for consumers. Recall the discussion about high streets. Retail frequently locates along an avenue, often for many blocks, but not on side streets. Why? In order for stores to be part of the same market, and thus benefit from market depth, consumers must be able to find one store from another. Stores arrayed along an avenue present shoppers with information - which stores sell what, how deep the market is, etc. Stores on side streets provide no such information. 
Enter mobile maps. Today, to find a shop or bar, consumers pull out a phone and look at Google Maps. Stores need not locate within sight of one another. In a world with mobile maps and searches, stores should locate in a neighborhood - not just along an avenue - effectively increasing the size of the "high street." Again, this is an economic gain. More properties participate in the agglomeration gains. Overall, retail density should increase, but the density should be more distributed along nowresidential side streets.

But Euclidean zoning is famously protective of residential zones. Zoning for retail is permitted along avenues, but largely barred on residential streets, even right next to major thoroughfares. The blocks between $5^{\text {th }}$ Avenue and Madison Avenue in the 6os, for example, are almost entirely zoned residential. ${ }^{12}$ Similarly, while retail might emerge on the roads in Brentwood that have seen Waze-induced traffic increases, zoning laws do not allow it. ${ }^{13}$

Third, GPS, mobile mapping and Waze make finding and getting to far-flung places much easier. Shortcuts to avoid traffic matter more the further you travel. These technologies should make living further away from work or stores more attractive, as they reduce travel time by providing better directions. Again, the effect is twofold. Mapping technologies should increase the overall size of metropolitan regions, as more people can commute to jobs, but also should spread that development out.

\subsection{B Transportation Network Companies and Residential Density}

Perhaps the most debated current innovation in transportation in recent years has been the rise of so-called transportation network companies (TNCs), or ride-hailing services, like Uber and Lyft (Rauch and Schleicher 2015). These companies create a two-sided market. On one side are riders, who press a button on their cell phones and hail a ride. On the other are drivers, either professionals or just people with cars, who agree through the service to drive a rider somewhere. The TNCs provide the mechanism for payment, reputational ranking of drivers and riders, and the technological backbone through which these transactions take place.

These services are both a technological advance and a regulatory "hack." The services use mobile technology to track the location of both parties, to connect them, and get one where she wants to go and the other some cash. This is an important technological innovation.

But the success of TNCs is also due to their capacity to overcome outdated regulation. Governments have traditionally limited taxi supply with something like a "medallion" system, and then regulated prices too (Wyman 2013). The result was undersupply and prices that were usually too high and sometimes too low (during periods of high demand). Uber and Lyft overcame local regulations by simply not complying with them, then using their political influence and vast customer base to push cities to normalize and legalize their product (Rauch and 
Schleicher 2015). Backed by incumbent taxi drivers, cities and states across the United States attempted to limit the entry of these firms. But they largely failed. With few exceptions, Uber and Lyft services are available in every major metropolitan area.

Uber and Lyft both provide new drivers with access to the taxi market and create variable "surge" pricing when there are fewer drivers than riders. Because Uber/Lyft drivers are not limited by traditional regulations, they can provide surge services. Many drivers only work during peak demand hours - like early morning or late afternoon, for example - because Uber is for them a part-time job (Hall and Krueger 2015). Drivers also provide specialized services like child seats or oversized cars for added prices in ways that traditional cabs could not (Uber 2016). Most importantly, they increase supply generally by making cars more available.

The effect of Uber and Lyft on the cab market has been profound. In a comparison between April and June in 2014 and 2015, Uber rides in New York City increased by 6 million and the number of yellow cab rides decreased by 4 million. The price of New York City taxi medallions has fallen from \$1.32 million to \$600,000. In San Francisco, since the introduction of Uber and Lyft, the number of taxi rides has fallen by more than half. Both Uber and Lyft now have extremely high market valuations - \$62.5 billion for Uber and \$5.5 billion for Lyft (Barro 2014; Newcomer 2016).

Along with a number of other firms like Via and Bridj, Uber and Lyft have moved into the jitney business as well. UberPool and LyftLine combine riders into cars, driving down prices further. Uber and Lyft say that their real goal is allowing people to live in cities without owning cars (Manjoo 2014). Travis Kalanick, the CEO of Uber, recently said, "Every car should be Uber" (Wagner 2015).

Despite these changes, few cities or regional planning agencies haves taken TNCs into account when creating long-run transportation and land use plans (Dupuis, Martin, and Rainwater 2015). This is a mistake.

To start, consider transit-oriented development. Cities frequently (and reasonably) seek to promote development next to new subway or light-rail locations, for both economic and environmental reasons. They want people to take the train and not drive. But valuable land right next to a given train station frequently gets turned into a parking lot since people have to get to the station somehow. This transforms some of the most valuable land - land right next to a station - into low-value parking spaces, where cars sit useless for the day.

TNCs can ameliorate this problem. Around 25 percent of Uber and Lyft rides are to and from mass transit stops (Higgs 2015; Holmes 2014). There have always been taxis at train stations, but the increased supply at peak hours and the ease of finding a driver make it much easier to get a cab to the station. Thus, TNCs mean more people can get to a train station without driving and parking a car. Further, these companies have increasingly partnered with the agencies that run rail lines to provide an integrated commuting product (Jaffe 2015). 
TNCs should allow greater density near train stations. More people living in more properties can use the station without driving there. Properties right next to stations will not need to be as tall; developers can build lower-rise but still-dense housing units, rather than parking lots, nearby. These can be transit-oriented since residents will not have to drive their own car to the train. Of course, the limiting factor is the cost of a taxi traveling a substantial distance, but TNCs should mean that for every train station, there are more carless developments - or rather, fewer cars per property.

This is somewhat generalizable. TNCs decrease the cost of trips longer than walking distance. Where buildings in cities used to have to be very dense if people were meant to travel between them without driving (or taking mass transit), now they can spread a bit further. This should produce the kind of "distributed density" that I mentioned earlier.

People writing about TNCs frequently ask whether they reduce car trips (Bialek, Fischer-Baum, and Mehta 2015). Surely they have both increased trips (when people take an Uber instead of walking or taking mass transit) and decreased trips (because people who use them for some trips instead of owning cars make fewer other trips). More important for land use purposes, though, is their effect on demand for parking and dense land uses.

TNCs should reduce demand for parking and increase demand for density generally. ${ }^{14} \mathrm{TNC}$ cars - like taxis - are either constantly in motion, and thus not parked, or are largely parked outside dense areas. As parking needs decrease, repurposing parking lots and garages could be a tremendous economic gain.

A shocking amount of urban land is devoted to parking; in many cities, surface parking and garages constitute more than 20 percent of all property (Gardner 2011), but not just because the market demands it. Zoning and subdivision laws require parking in unbelievable ways. New housing, for example, frequently has to provide at least one parking space per bedroom, which is substantially more than developers who do not have to comply with minimums provide (McDonnell 2011, Shoup 2005 130-50). These requirements can have huge effects. Donald Shoup has shown they add 18 percent to the cost of construction and reduce land value by 33 percent of the cost of apartments in Oakland. For other uses, the effects are even greater. For instance, the "Golden Rule" for local zoning ordinances for office buildings is four spaces per 1,000 square feet of rentable office space. As long as such rules exist, the country will not see all of the economic gains from TNCs.

Similarly, TNC should increase demand for urban property generally, as it makes it easier to get around in cities. But to the extent land use laws limit urban density, the benefits of TNCs are wasted.

\subsection{Autonomous Cars}

Technologists are getting closer and closer to developing autonomous, or selfdriving, cars. ${ }^{15}$ The idea is intoxicatingly futuristic. Riders will input an address, 
and a car without a driver will take them there far more safely than any human driver could. Google has developed and road tested autonomous cars in several cities, logging a combined 1 million miles. Google claims that such cars will be generally available by 2020 (Korosec 2016; Lee 2015b). Similarly, Uber has spent millions and partnered with Carnegie Mellon University's robotics department to develop autonomous cars (and ultimately hired away most of CMU's team) (Thompson 2015). Not to be outdone, Tesla has invested in self-driving cars, and CEO Elon Musk declared that fully autonomous cars are only a "few years away" (Hollister 2015). In its last year, the Obama administration proposed spending \$4 billion over the next 10 years to study autonomous cars, and promised to develop regulations to enable their use (Spector and Ramsey 2016). Even traditional automakers have gotten in on the action, although most of their activity has been in developing partially autonomous driving features. But General Motors invested \$500 million in Lyft as part of a joint project to build autonomous cars. Toyota, Nissan, Ford, and others are investing heavily in fully autonomous vehicles, some targeting as early as 2020 for commercial availability (Vanian 2016).

Obviously, challenges to the technology remain. In particular, these cars do not yet react well to other drivers or to changing weather conditions (Lee 2015b). But if they can overcome these challenges, autonomous cars will revolutionize transportation. They should reduce car crashes, the twelfth leading cause of death of Americans, and make travel easier (National Highway Traffic Safety Administration 2015). The potential change to the economy presented by autonomous cars is on a different scale from the innovations discussed earlier - it might be truly transformative.

Thus far, governments seem confused about how to regulate them. California is considering regulations that will require a licensed driver available to take over for the machine, for instance (Vekshin 2016). More pressing for our purposes here, states and localities are not sure how to think about the effect of autonomous cars on land use planning. Although the arrival of autonomous cars seems somewhat imminent, only 6 percent of long-term regional transit and land use plans mention them, and government officials around the country have expressed doubts about how they will respond to developments (Dupuis et al. 2015; Guerra 2015).

This lack of planning follows from two factors: first, uncertainty about when these cars will be available; second, and more interesting, how they will be used. Scholars and technologists have suggested two possible models.

The first possibility is that autonomous cars will be used like taxis (Fagnant, Kockelman, and Bansal 2015; Lee 2015a; Neil 2015). The cars would be constantly in motion, waiting to be summoned by a rider. If this happens, they will drive down the cost of taking a cab significantly. Some models suggest that costs could fall by as much as 80 percent, though other models suggest more modest savings - around 33 percent (Burns, Jordan, and Scarborough 2013; Fagnant et al. 2015). Either way, many urban dwellers will choose to buy minutes of mobility rather than own their 
own cars. The need for parking would go down massively, as many fewer cars could provide the same or more rides (Anderson et al. 2014).

This suggests that autonomous cars will have the same type of effect on land uses, then, as TNCs, but on a far, far greater scale. Autonomous cars will contribute meaningfully to urban density by making it easier to get around dense areas and by reducing the space wasted on parked cars. Further, they will expand the area that can be described as "downtown," allowing urban density to spread a bit even as it increases. ${ }^{16}$

Another possibility exists (Ohnsman 2014; Smith 2015). Autonomous cars may simply replace driver-operated ones. If this occurs, most people will own an autonomous car and leave it parked when they stop to get to their home, office, or stores. Autonomous cars will surely make regions more spread out. People will be willing to have longer commutes as they will not need to drive themselves, making commuting time more productive (or more fun) (Anderson et al. 2014). Under this model, selfdriving cars will result in more sprawling metropolitan areas.

Which model will win out? Perhaps some combination of both. The cost of producing self-driving cars and the path technological innovation takes will both be factors. But so too will land use law. Taxis make sense in dense places, where most rides are short. In spread-out exurbs, however, taxi services make less sense. If people are spread out, cars cannot be nearby when requested. While self-driving cars will permit greater (but distributed) densities, they also need such densities to be useful as taxis. If such density is not permitted, there will be little incentive to build cars to fit that use. That is, land use laws will partially drive technological development.

\subsection{THE PROBLEM OF CREATING DISTRIBUTED DENSITY WITH EXISTING LAND USE PROCEDURES AND POLITICS}

If we hope to maximize the economic gains from transportation technologies that techno-optimists predict, we must overcome certain pathologies in our land use policy and politics. These pathologies persist most strongly in urban cores, so those areas will see the most limited economic growth from transportation innovation. In this section, I plan to outline these pathologies and their effects on economic growth.

To start, American law confines land to certain uses quite stringently. As Sonia Hirt argues, the central goal of the creation of American zoning law was the protection of exclusively residential neighborhoods (2013). Today, we restrict land to residential uses - and particularly, detached single-family homes - to a far greater degree than any other country. Even on blocks right next to commercial high streets, it is common to find exclusively residential zones. This prevents stores from locating on side streets that intersect a given high street. American land use law's emphasis on separation frustrates the potential benefits of GPS and mobile mapping for broadening the potential places in which retail exists. 
Further, modern land use law prevents "distributed density" in many of our biggest, richest cities. For instance, Glaeser, Gyourko, and Saks estimate the "zoning tax" - the difference between the price of housing and the cost of building housing to be more than 50 percent in Manhattan (2005).

Regulations that disfavor the "missing middle" of housing account for much of this loss (Hurley 2016; Missing Middle 2016). While older cities have lots of midsized housing, newer-built cities depend largely on either single-family homes or multiunit apartment buildings (Badger and Ingraham 2015). For instance, the most common form of housing in Boston is the "triple-decker," a three-unit, small apartment building. But almost none of them have been built in the past 50 years (Cloutier 2015). This is not because of a lack of demand - prices are soaring on units in triple-deckers in much of the Boston area - but rather because it is illegal to build them in many places.

This is a product of deeply embedded aspects of land use procedure and law, as I have outlined in a series of articles that I will summarize here (Hills and Schleicher 2011, 2015; Schleicher 2013). Most zoning changes happen through neighborhood-specific amendments, rather than as the product of citywide deals. In currently low-rise areas, this often leads to zoning amendments - "downzonings" in the parlance - that prevent any or much as-of-right development. In the absence of citywide partisan competition (something most big cities lack), city councils frequently give members "councilmanic privilege" - the exclusive capacity to make decisions about land use changes in their district. Downzonings succeed because there are no real opponents (no developer has yet made an investment), and nearby homeowners support them as tools to cartelize the housing stock and to avoid externalities from new construction. Even cities with political leaders publicly committed to housing growth, like New York City under Mayor Michael Bloomberg, approve many such downzonings.

As a result, in desirable areas in many cities, there is little or no as-of-right development. Of course, this does not mean that there is no new development. Cities can and do approve new zoning amendments to allow growth. But they only do so either when they can charge high fees - through impact fees, affordable housing requirements, or indirectly through things like community benefits agreements - or when a big developer has the political wherewithal to push a project through the difficult land use review process and subsequent litigation. Or both.

Because of this political, administrative, and legal thicket, the only types of amendments that will succeed are those that provide massive gains to their proponents. Repeat-player developers proposing big new buildings may have the resources and political sophistication to overcome NIMBY opposition and convince the city to approve a zoning amendment. But incremental housing growth becomes nearly impossible. While big developers in theory could develop lots of mid-rise housing (and sometimes do), the problems of lot assembly are severe. The result is the "missing middle" - towers but not triple-deckers. 
But there is much less regulation on the urban fringe. There, underdeveloped local governments generally allow growth. Further, many Southern and Sun Belt cities - like Atlanta and Houston - have much less strict land use restrictions. Transportation technologies therefore will create the most economic gains on the urban fringe and in less regulated urban areas. In the richest and most productive parts of the country, in contrast, these gains will be largely squandered.

\subsection{CONCLUSION: FIXING LAND USE TO GET THE MOST OUT OF TRANSPORTATION INNOVATION}

The simplest answer to the question of what can be done is to change our zoning laws. Allow retail in residential areas. Allow more density generally and more midrise construction specifically. And so forth. But many people like our land use laws, so they are hard to dislodge. As Richard Babcock noted, "No one is enthusiastic about zoning except the people" $(1966,17)$. Rather than simply advocating for change, reformers should focus on changing the political structure of decision making or the incentives for homeowners.

First, transit innovators should push for changes in land use procedure. In the past, I have proposed that cities adopt "zoning budgets" (Hills and Schleicher 2011; Schleicher 2013). Local government would set a target for the number of new houses that should be built over a period of time. Until that target is met, no "downzonings" are allowed; after the target is hit, all downzonings would have to be matched by comparable rezonings for greater capacity. Nothing about adopting a budget would directly cause housing growth - a city could choose zero or a negative number. But if cities decide the amount of growth at the outset, neighborhoods will not shut off development out of fear that they will become dumping grounds.

"Zoning budgets" offer another benefit. If land use decisions regularly took place at the citywide level, employers and transportation companies would become interested in the issue. Currently, no individual zoning amendment affects the housing supply enough to attract lobbying by general business interests. But employers should want more supply. Lower housing prices mean greater real value for the wages they offer.

The same goes for TNCs, since greater density should lead to greater profits for them. If decisions were made citywide, employers would have a strong incentive to lobby for housing growth against the narrower interests of particular communities. Adopting zoning budgets or like procedures would allow transportation companies to become players in land use.

Second, advocates could use transportation benefits to bribe NIMBYs. Developers have long paid opponents to allow them to build, usually through exactions or community benefits agreements (Been 2010). These bribes increase the cost of housing, of course, but transportation companies might be able to limit this increase. For example, developers often bribe NIMBYs with parking spaces, so that new neighbors do not take up existing parking. But some cities 
have allowed or required developers to replace these parking-space bribes with car-sharing contracts, substituting a ZipCar for a few parking spaces (Rauch and Schleicher 2015). Since these benefits are cheaper than parking spaces, the transportation company can reduce the "tax" on new housing. The next step might be doing the same thing with TNCs. Cities could require that developers provide residents with annual Uber or Lyft gift certificates instead of building parking. If TNCs played along (with discounts), you might see greater density instead of more parking (and more demand for TNC use).

These are just a few possible reform ideas. If these technologies are to succeed, firms like Uber and Lyft, Google and Tesla must begin to fight for these important land use reforms. Otherwise, the economic benefits of these incredible, innovative transportation technologies will be squandered.

\section{AUTHOR'S NOTE}

I would like to thank Christine Kwon and Garrett West for providing terrific research assistance. I would also like to thank Deven Bunten, Anika Singh Lemar, and Matthew Yglesias for insightful comments. All errors are my own, of course.

\section{REFERENCES}

Aditjandra, Paulus Teguh. 2013. "The Impact of Urban Development Patterns on Travel Behavior: Lessons Learned from a British Metropolitan Region Using Macro-analysis and Micro-analysis in Addressing the Sustainability Agenda." Research in Transportation Business \& Management 7 (July): 69-80.

Aldana, Karen. 2013. "U.S. Department of Transportation Releases Policy on Automated Vehicle Development." National Highway Traffic Safety Administration (press release). May 30. www.nhtsa.gov/About+NHTSA/Press + Releases/U.S.+Department+of + Transportation+Releases+Policy+on + Automated+Vehicle+Development.

Anderson, James M., Nidhi Kalra, Karlyn D. Stanley, Paul Sorenson, Constantine Samaras, and Oluwatobi A. Oluwatola. 2014. Autonomous Vehicle Technology: A Guide for Policy Makers. Santa Monica, CA: RAND Corporation. www.rand.org/content/dam/rand/pubs/research_re ports/RR400/RR443-1/RAND_RR443-1.pdf.

Babcock, Richard F. 1966. The Zoning Game: Municipal Practices and Policies. Madison: University of Wisconsin Press.

Badger, Emily and Christopher Ingraham. 2015. "The Most Popular Type of Home in Every Major American City, Charted." Washington Post. September 21. www.washingtonpost.com/news/wonk/wp/2015/og/21/the-most-popular-type-of -home-in-every-major-american-city-charted/. 
Barro, Josh. 2014. "Under Pressure from Uber, Taxi Medallion Prices are Plummeting." New York Times. November 14. www.nytimes.com/2014/11/28 /upshot/under-pressure-from-uber-taxi-medallion-prices-are-plummeting.html.

Barron, David J. 2003. "Reclaiming Home Rule." Harvard Law Review 116(8): $2255^{-23} 86$.

Been, Vicki. 2010. "Community Benefit Agreements: A New Local Government Tool or Another Variation on the Exactions Theme?" The University of Chicago Law Review 77(1): 5-35.

Bertaud, Alain. 2014. "Cities as Labor Markets.” Working Paper \#2, Marron Institute of Urban Management, New York University, New York, NY. http://marronin stitute.nyu.edu/uploads/content/Cities_as_Labor_Markets.pdf.

2004. "The Spatial Organization of Cities: Deliberate Outcome or Unforeseen Consequence?” Working Paper 2004-01, Institute of Urban and Regional Development, University of California, Berkeley, Berkeley, CA. http://escholar ship.org/uc/item/5vb4wowb.

Bialek, Carl, Reuben Fischer-Baum, and Dhrumil Mehta. 2015. "Is Uber Making NYC Rush-Hour Traffic Worse?” FiveThirtyEight. December 9. http://fivethir tyeight.com/features/is-uber-making-nyc-rush-hour-traffic-worse/.

Brownell, Brett. 2014. "The 2000-Year History of GPS Tracking." Mother Jones. April 15, www.motherjones.com/mixed-media/2014/o4/you-are-here-book-hiawatha -bray-gps-navigation.

Brynjolfsson, Erik and Andrew McAfee. 2014. The Second Machine Age: Work, Progress, and Prosperity in a Time of Brilliant Technologies. New York: W. W. Norton.

Brynjolfsson, Erik and Paul Milgrom. 2013 "Complementarity in Organizations." In The Handbook for Organization Economics, Robert Gibbons and John Roberts, eds. Princeton, NJ: Princeton University Press.

Burns, Lawrence D., William C. Jordan, and Bonnie A. Scarborough. 2013. "Transforming Personal Mobility." Working Paper, Earth Institute, Columbia University, New York, NY, January 27. http://sustainablemobility.ei.columbia .edu/files/2012/12/Transforming-Personal-Mobility-Jan-27-20132.pdf.

Cloutier, Catherine. 2015. "Boston's Triple-Deckers in Demand, Families Getting Pushed Out." Boston Globe. October 8. www.bostonglobe.com/metro/2015/10 108/boston-three-deckers-remain-mainstay-but-bigger-buildings-are-rise /s15Oc6pXMXHe8sB2wLoUZK/story.html.

DuPuis, Nicole, Cooper Martin, and Brooks Rainwater. 2015. City of the Future: Technology and Mobility. Washington, DC: National League of Cities. www .nlc.org/Documents/Find\%2oCity\%2oSolutions/Research\%2oInnovation/City $\%$ zoof\%zothe\%zoFuture/City\%zoof\%zothe\%zoFuture\%zoFINAL\% 2०WEB.pdf.

Edlund, Lena, Cecilia Machado, and Maria Micaela Syiatschi. 2015. "Bright Minds, Big Rent: Gentrification and the Rising Returns to Skill." NBER Working Paper No. 21729, National Bureau of Economic Research, November. www.nber.org /papers/w21729.

Fagnant, Daniel J., Kara M. Kockelman, and Prateek Bansal. 2015. "Operations of a Shared Autonomous Vehicle Fleet for the Austin, Texas Market." Presentation, 
94th Annual Meeting of the Transportation Research Board, Washington, DC, January. www.caee.utexas.edu/prof/kockelman/public_html/TRB ${ }_{15} \mathrm{SAV}$ sin Austin.pdf.

Fischel, William A. 2015. Zoning Rules!: The Economics of Land Use Regulation. Cambridge: Lincoln Institute of Land Policy.

Foster, Mark S. 1981. From Streetcar to Superhighway: American City Planners and Urban Transportation, 1900-1940. Philadelphia, PA: Temple University Press. Fujita, Masahisa, Paul Krugman, and Anthony J. Venables. 1999. The Spatial Economy: Cities Regions, and International Trade. Cambridge, MA: MIT Press.

Ganong, Peter and Daniel Shoag. 2014. "Why Has Regional Income Convergence in the U.S. Declined?” HKS Working Paper No. RWP12-o28, Harvard Kennedy School, Cambridge, MA, March 28. http://papers.ssrn.com/sol3/papers.cfm ?abstract_id=2081216\#\#.

Gardner, Charlie. 2011. "We Are the 25\%: Looking at Street Area Percentages and Surface Parking." Old Urbanist. December 12. http://oldurbanist.blogspot.com /2011/12/we-are-25-looking-at-street-area.html.

Glaeser, Edward L. 2010. “Cities Do It Better.” Economix. New York Times. April 27. http://economix.blogs.nytimes.com/2010/04/27/cities-do-it-better/?_r=o.

2008a. Cities, Agglomeration, and Spatial Equilibrium. Oxford: Oxford University Press.

2008b. “The Economic Approach to Cities." Discussion Paper No. 2149, Harvard

Institute of Economic Research, January. ftp://ftp.repec.org/RePEc/fth/harver /hier2149.pdf.

2008c. "Houston, New York has a Problem." City Journal. www.city-journal.org /2008/18_3_houston.html.

Glaeser, Edward L. and Janet Kohlhase. 2004. "Cities, Regions and The Decline of Transport Costs." Regional Science 83 (January): 197-228.

Glaeser, Edward L. and David C. Mare. 2001. "Cities and Skills." Journal of Labor Economics 19(2): 316-42.

Glaeser, Edward L. and Giacomo A. M. Ponzetto. 2007. "Did the Death of Distance Hurt Detroit and Help New York?” Working Paper No. 13710, National Bureau of Economic Research, December. www.nber.org/papers/w13710.pdf.

Glaeser, Edward L., Joseph Gyourko, and Raven Saks. 2005. "Why Is Manhattan so Expensive? Regulation and the Rise in Housing Prices." Journal of Law and Economics 48 (October): 331-69.

Gordon, Robert J. 2014. "The Demise of U.S. Economic Growth: Restatement, Rebuttal, and Reflections." NBER Working Paper No. 19895, National Bureau of Economic Research, January 20. http://content.csbs.utah.edu/ mli /Economics\%207004/Gordon_NBER\%20P383F\%20Sequel_140126.pdf.

Guerra, Erik. 2015. "Planning for Cars That Drive Themselves: Metropolitan Planning Organizations, Regional Transportation Plans, and Autonomous Vehicles." Journal of Planning Education and Research (November 2): 1-15. http://jpe.sagepub.com/content/early/2015/10/29/0739456X15613591.abstract. 
Hall, Jonathan V. and Alan B. Krueger. 2015. "An Analysis of the Labor Market for Uber's Driving-Partners in the United States." Working Paper \# 587, Industrial Relations Section, Princeton University, Princeton, NJ, January. http://data space.princeton.edu/jspui/handle/88435/dspo10z708z67d.

Higgs, Larry. 2015. "Uber Took 300 K N.J. Commuters to the Bus or Train Last Month.” NJ.com: True Jersey. October 27. www.nj.com/traffic/index.ssf/2015/10 /uber_took_30ok_nj_commuters_to_the_bus_or_train_last_month.html.

Hills, Roderick M., Jr., and David N. Schleicher. 2015. "Planning an Affordable City." Iowa Law Review 101(1): 91-136. http://ilr.law.uiowa.edu/files/ilr.law .uiowa.edu/files/ILR_101-1_Hills\%26Schleicher.pdf.

2011. "Balancing the Zoning Budget." Case Western Law Review 62(1): 81-134. http:// heinonline.org/HOL/Page?handle=hein.journals/cwrlrv62\&g_sent=1\&id=84.

Hirt, Sonia. 2013. "Form Follows Function? How America Zones." Planning, Practice G Research 28(2): 204-30. http://dx.doi.org/10.1080/02697459.2012.704736.

Hollister, Sean. 2015. "Elon Musk Describes the Future of Self-Driving Cars." Gizmodo. March 18. http://gizmodo.com/elon-musk-describes-the-future-of -self-driving-cars-1692076449.

Holmes, Jeremy. 2014. "Uber, Lyft May Add Convenience ... And Traffic Jams." Mobility Lab. September 24. http://mobilitylab.org/2014/og/24/uber-lyft-may -add-convenience-and-traffic-jams/.

Hsieh, Chang-Tai and Enrico Moretti. 2015. "Why Do Cities Matter? Local Growth and Aggregate Growth." NBER Working Paper No. 21154, National Bureau of Economic Research, May. www.nber.org/papers/w21154.pdf.

Hurley, Amanda Kolson. 2016. "Will U.S. Cities Design Their Way Out of the Affordable Housing Crisis?" Next City. https://nextcity.org/features/view/cities -affordable-housing-design-solution-missing-middle.

Jaffe, Eric. 2015. "Uber and Public Transit Are Trying to Get Along." CityLab, August 3. www.citylab.com/cityfixer/2015/o8/uber-and-public-transit-are-trying -to-get-along/400283/.

Jaffee, Adam B. et al. 1993. "Geographic Localization of Knowledge Spillovers as Evidenced by Patent Citations." Quarterly Journal of Economics, 108: 577 .

Korosec, Kirsten. 2016. "Google Preparing to Expand Self-Driving Car Program to Four More Cities." Fortune. January 29. http://fortune.com/2016/o1/29/google -self-driving-cars-cities/.

Krugman, Paul. 1995. Development, Geography, and Economic Theory. Cambridge, MA: MIT Press.

Lee, Timothy B. 2015a. "Driverless Cars Will Mean the End of Mass Car Ownership." Vox. January 31. www.vox.com/2014/5/28/5758560/driverless-cars -will-mean-the-end-of-car-ownership.

2015b. "Self-Driving Cars Have Logged a Million Miles on the Roads. Here's Their Safety Record." Vox. October 30. www.vox.com/technology/2015/10/30 19640230/self-driving-car-crashes.

Lewyn, Michael. 2008. "Sprawl in Europe and America." Working Paper. http:// papers.ssrn.com/sol3/papers.cfm?abstract_id=1194862. 
Logan, John R. and Harvey L. Molotch. 1987. Urban Fortunes: The Political Economy of Place. Berkeley: University of California Press.

Manjoo, Farhad. 2014. "With Uber, Less Reason to Own a Car." New York Times. June 11. www.nytimes.com/2014/06/12/technology/personaltech/with-ubers -cars-maybe-we-dont-need-our-own.html?_r=o.

Marshall, Alfred. 189o. Principles of Economics. London: Macmillan.

McDonnell, Simon, et al. 2011. "Minimum Parking Requirements and Housing Affordability in New York City." Housing Policy Debate, 21(1).

McShane, Clay and Joel Tarr. 2007. The Horse in the City: Living Machines in the Nineteenth Century. Baltimore, MD: Johns Hopkins University Press.

Miller, Jake. 2015. "Obama: Auto Industry 'Leading the Way' in America's Comeback." CBS News. January 7. www.cbsnews.com/news/obama-auto -industry-leading-the-way-for-americas-comeback/.

Missing Middle. 2016. "Missing Middle: Responding to the Demand for Walkable Urban Living." http://missingmiddlehousing.com/.

Mohl, Raymond A. and Roger Biles. 2012. The Making of Urban America. Plymouth: Rowman \& Littlefield Publishers.

Mueller, Benjamin. 2014. "In Connecticut, Breaking Barrier Between a Suburb and Public Housing." New York Times. July 11. www.nytimes.com/2014/o7/12/nyregion /in-connecticut-breaking-barrier-between-a-suburb-and-public-housing.html?_r=o.

National Highway Traffic Safety Administration. 2015. Traffic Safety Facts: Research Note. DOT-HS-812-203. Washington, DC. October. www-nrd.nhtsa.dot.gov /Pubs/812203.pdf.

Neil, Dan. 2015. “Could Self-Driving Cars Spell the End of Ownership?” Wall Street Journal. December 1. www.wsj.com/articles/could-self-driving-cars-spell-the -end-of-ownership-1448986572.

Newcomer, Eric. 2016. "G.M. Invests \$500 Million in Lyft." Bloomber, January 4. https://www.bloomberg.com/news/articles/2016-o1-o4/gm-invests-50o-million -in-lyft-to-bolster-alliance-against-uber

Norton, Peter D. 2011. Fighting Traffic: The Dawn of the Motor Age in the American City. Cambridge, MA: MIT Press.

Ohnsman, Alan. 2014. "Automated Cars May Boost Fuel Use, Toyota Scientist Says." Bloomberg. July 16. www.bloomberg.com/news/articles/2014-07-16/auto mated-cars-may-boost-fuel-use-toyota-scientist-says.

Pace, Scott, et al. 1995. The Global Positioning System: Assessing National Policies, Washington, DC: RAND Corporation Press.

Patterson, Robert W. 2013. "What's Good for America ..." National Review. July 1. www.nationalreview.com/article/352429/whats-good-america-robert-w-patterson.

Plato. 1931. The Republic. In The Dialogues of Plato (3rd edition). Translated by B. Jowett. Oxford: Oxford University Press.

Platt, Rutherford H. 2004. Land Use and Society, Revised Edition: Geography, Law, and Public Policy. Washington, DC: Island Press.

Rauch, Daniel E. and David Schleicher. 2015. "Like Uber, but for Local Government Law: The Future of Local Regulation of the Sharing Economy." Ohio State Law Journal 76: 901-63. 
Rodriguez, Daniel B. and David Schleicher. 2012. "The Location Market." George Mason Law Review 19(3): 637-64.

Schleicher, David. 2013. "City Unplanning." Yale Law Journal 122(7): 1670-1737. 2010. "The City as a Law and Economic Subject." University of Illinois Law Review 2010: 1507-63.

Shoup, Donald. 2005. The High Cost of Free Parking. 130-50. Chicago: American Planning Association Planners Press.

Silverman, Rachel Emma. 2013. "The Science of Serendipity in the Workplace."

Wall Street Journal. April 30. www.wsj.com/articles/SB1000142412788732 3798104578455081218505870.

Smith, Bryant Walker. 2013. "Managing Autonomous Transportation Demand." 52 Santa Clara Law Review 52 (4) 1401-1422.

Smith, Noah. 2015. "Like the Suburbs? You'll Love Driverless Cars." BloombergView. November 4. www.bloombergview.com/articles/2015-11-04 /ike-the-suburbs-you-ll-love-driverless-cars-.

Spector, Mike and Mike Ramsey. 2016. "U.S. Proposes Spending \$4 Billion to Encourage Driverless Cars.” Wall Street Journal. January 14. www.wsj.com /articles/obama-administration-proposes-spending-4-billion-on-driverless-car -guidelines-1452798787.

Thompson, Clive. 2015. "Uber Would Like to Buy Your Robotics Department." New York Times Magazine. September 11. www.nytimes.com/2015/og/13/magazine /uber-would-like-to-buy-your-robotics-department.html.

Uber. 2016. "UberFAMILY: For Parents on the Go." UberNewsroom. https://news room.uber.com/us-new-york/uberfamilyfor-parents-on-the-go/.

2015. "Driving Solutions to Build Smarter Cities." UberNewsroom. https://news room.uber.com/us-massachusetts/driving-solutions-to-build-smarter-cities/.

Van Wee, Bert. 2015. "Viewpoint: Toward a New Generation of Land Use Transport Interaction Models." Journal of Transport and Land Use 8(3): 1-10, www.jtlu.org /index.php/jtlu/article/viewFile/611/710.

Vanderbilt, Tom. N.d. "Waze: The App That Changed Driving." Gear Lab. Men's Journal. www.mensjournal.com/gear/cars/waze-the-app-that-changed-driving -20160208 .

Vanian, Jonathan. 2016. "Toyota Hires Artificial Intelligence Gurus for Self-Driving Cars." Fortune. January 5. http://fortune.com/2016/o1/05/toyota-hires-artifical -intelligence-expert/.

Vekshin, Alison. 2016. "Self-Driving Cars Would Need a Driver in California." Bloomberg. January 28. www.bloomberg.com/news/articles/2016-o1-28/self-driv ing-cars-would-need-a-driver-under-california-rules.

Wagner, Davis. 2015. "Uber CEO Travis Kalanick: Every Car Should Be Ours." InformationWeek. September 16. www.informationweek.com/cloud/uber-ceo -travis-kalanick-every-car-should-be-ours/d/d-id/1322212.

Wallace-Wells, Benjamin. 2015. "Waze and the Politics of Public Spaces." New York Magazine. January 30. http://nymag.com/daily/intelligencer/2015/o1/waze-and -the-politics-of-public-spaces.html. 
Wegener, Michael. 2014. “Land-Use Transport Interaction Models." In Handbook of Regional Science, Manfred M. Fischer and Peter Nijkamp, eds. Berlin: Springer-Verlag. http://link.springer.com/referenceworkentry/10.1007/978-3 $-642-23430-9-41$.

2013. "The Future of Mobility in Cities: Challenges for Urban Modelling." Transport Policy 29 (September): 275-82.

"Why Autonomous and Self-Driving Cars are Not the Same." 2015. Economist. July

1. www.economist.com/blogs/economist-explains/2015/o7/economist-explains.

Wyman, Katrina. 2013. "Problematic Private Property: The Case of the New York Taxicab Medallion." Yale Journal on Regulation 30: 125-88.

Yglesias, Matthew. 2012. The Rent Is too Damn High: What to Do about It, and Why It Matters More Than You Think. New York: Simon \& Schuster.

\section{Notes}

1. First by Plato and then by others (Plato 1931).

2. It is worth asking whether transportation innovation is really distinct in this respect. Some have argued, for instance, that information technology innovations will have a greater effect on growth in the future as we change things like the internal organization of firms (Brynjolfsson and Milgrom 2013). Not much turns on this for this chapter, as transportation more than other innovations turns on changes in land use.

3. In manufacturing, elevators play a crucial but distinct role.

4. As I will discuss later, a similar logic applies to "car sharing" or short-term car rental services like ZipCar and CarzGo.

5. I should be careful here. That technological development responds to a regulatory universe does not mean that it is suboptimal. Regulations may make things better, after all. But in this case, it seems likely that allowing these technologies to work well in far-flung areas but not in denser ones will make existing pathologies (against density, environmental problems) worse.

6. Congestion in this literature consists of the higher rents in urban areas, the negative externalities of density (traffic, dirt, easily passed germs), and what I have called in the past "negative agglomerations," or activities that see agglomeration gains but that are socially costly, like crime (Schleicher 2010).

7. Lest you think this is a metaphor, the town of Hamden, CT, built a chain-link fence that separated it and the public housing projects in New Haven and kept it up from the 195 os through 2014 (Mueller 2014).

8. A few commentators at the conference associated with this volume asked whether, contrary to the arguments made by me, Hsieh and Moretti, and Glaeser, it might be better to use public policy to spread people out to urban centers that they would not otherwise choose, as different people will be exposed to those individuals' agglomeration externalities. This critique, which is brought up frequently enough, is not theoretically wrong. Agglomeration economies are by their very nature, externalities, and therefore it is theoretically possible to use policy to fix market failures. But, as Daniel Rodriguez and I have argued 
(Rodriguez and Schleicher 2012), the critique is premised on both a deep distrust of the ability of property markets to function well and a high degree of faith in the ability of governments to measure and dole out agglomeration externalities optimally. There is no reason to believe that a real national governmental social planner can outperform the property market in allocating people across regions, and even less to reason to believe that the self-interested behavior of hundreds of local governments will. The optimal land use policy, Rodriguez and I contend, is to be as neutral as possible about locational choices at the neighborhood or regional level absent some very strong specific justification. The technological innovations discussed here expand the choice set for individuals about where to move, but do not require much forethought by local officials about which locational choices are best for specific people.

9. The same force also causes gentrification - if construction in rich areas is impossible, people who want to live in those areas have to move to other areas, increasing prices elsewhere (Yglesias 2012).

10. Sorry, Shirlington!

11. They not only spread out existing cars, but they surely increase the number of cars on the road. This is a product of what transit planners call "induced demand." In short, new roads create traffic by reducing the cost of driving, thus encouraging people to drive more. Usually, people who talk about induced demand use it as an argument against building new roads, on the grounds that these new roads are sure to become congested. In extremis, this argument doesn't make a whole lot of sense - it applies equally to the first road built as to the last one. The point of roads is to make it easy to drive places, and we should judge their utility by whether the increased capacity is worth the costs (including externalities like carbon emissions). What is true is that new roads are not likely to get rid of traffic because of induced demand (solving traffic would require addressing the externality created by your car for all others behind it, something that can really be addressed only with congestion charges). So too with Waze. It is not likely to reduce traffic - it will and does induce demand - but it may allow more cars to use the same number of roads.

12. See ZOLA, New York City's terrific zoning web application. The zoning along these streets is largely R8B, or roughly for tall, brownstone houses. www.nyc.gov /html/dcp/html/zone/zh_r8b.shtml.

13. The reader should search ZIMAS, Los Angeles' zoning map application: http:// zimas.lacity.org. While there are existing commercial strips on San Vicente in Brentwood, no new strip could emerge - and those are already totally full.

14. The same point also applies to short-term car rentals like ZipCar and CarzGo. These services are useful only in relatively dense areas, as the rentals have to be returned to a permissible parking place. And as they are used by many rather than individually, they cut down on overall parking used.

15. To be a bit more technical, the National Highway Traffic Safety Administration has announced five categories of "automation" - Level o (fully driver-operated); Level 1 ("function-specific automation" like electronic stability control); Level 2 ("combined function automation" like adaptive cruise control combined with 
lane centering); Level 3 ("limited self-driving" or mixed driver control and autonomous driving); and Level 4 ("fully autonomous") (Aldana 2013; "Why Autonomous and Self-Driving Cars Are Not the Same" 2015). For the purposes here, I am talking about Level 4.

16. Unlike TNCs, it is pretty clear they will increase vehicle miles traveled (Smith 2013). 